\title{
Guided Inquiry Model with the REACT Strategy Learning Materials to Improve the Students' Learning Achievement
}

\author{
Miftahul Jannah ${ }^{1}$, Z. A. Imam Supardi ${ }^{2}$, Prabowo ${ }^{3}$ \\ 1,2,3Universitas Negeri Surabaya, Surabaya, Indonesia
}

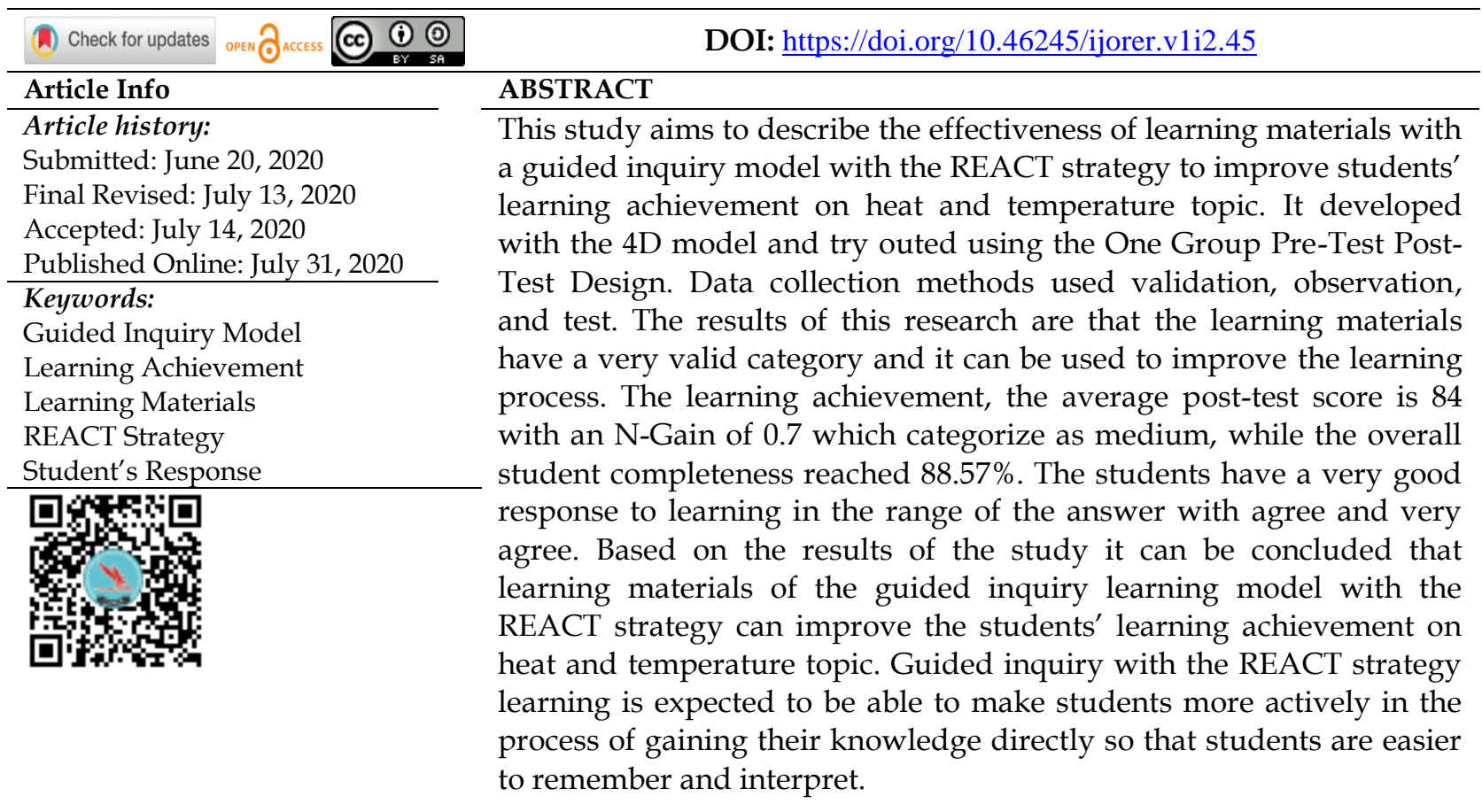

\section{INTRODUCTION}

Education is an important major factor to determine the progress of a nation and state. Every human needs education in their life. With education, the humans will be developed. Humans can be developed by a process namely learning. Learning is a process that is marked by changes in human beings. Change as a result of various forms such as changes in attitudes, understanding of knowledge, behavior, skills, habits, and changes in other aspects that exist in individuals who learn (Baharuddin, 2014). One of the goals of education is to realize the conditions of learning and teaching so that students can be actively to develop their ability to have spiritual strength, personality, self-control, intelligence, noble character, and skills needed by themselves, society, nation and country. Education must have a good quality, with the quality education will produce quality human resources as well. For achieving these goals, students must have interacted with the learning environment and teacher to obtained the learning process. In the teaching and learning activities, the teacher must pay attention to the curriculum used. One of the curricula that are used in Indonesia now is Curriculum 2013.

Curriculum 2013 is more emphasizes on authentic assessment and strengthening the process of competency learning activities (Kesuma et al., 2019). The students are encouraged to be more masterful in the " $5 \mathrm{M}$ " activities are observing, asking, trying, reasoning, and communicating which is done with a scientific approach. The learning 
process must be changed from "telling" to "helping students to become aware of" which can be done through the process of scientific inquiry. So, the learning must actively involve the student in finding concepts or problem solving that it can be done through inquiry learning. One of the inquiry learning that can be used is guided inquiry learning.

Guided inquiry learning model is a learning process to obtain the information by observing or experimenting to find answers or solve the problems to questions or formulate problems using critical and logical thinking skills (Mohamad, 2011). The inquiry learning also can be defined as the process of formulating problems based on the phenomena and looking for the answers themselves (Suparno, 2013). Furthermore, Muhafid defines that the inquiry learning as the process to get information or knowledge by observation or experimental activities used to solve the problems with the formulation of problems or questions using critical and logical thinking skills (Muhafid, 2015). Eggen and Kauchak said that the inquiry learning model has six steps as follows: (1) identifying the problem; (2) formulating a hypothesis; (3) data collecting; (4) data analyzing; (5) making conclusions; and (6) reflection (Friesen, 2012). Based on the description above, it can be concluded that the guided inquiry learning model is a teaching and learning process to involved the student's thinking ability to systematically investigate a problem which is included the identification and asking the questions related to the problem, formulating a hypothesis, collecting data by observing or experimenting to answer the questions and test hypotheses that it has been made based on the facts and draw the conclusions. This learning process is student-centered, and teacher-only acts as a guide and facilitator.

The learning process of inquiry has a long term effect on students' scientific literacy. The conventional teaching can be replaced with inquiry-based learning will not interfere with the performance of students' school achievements. Students with secondary school performance are showed the most active involvement in the investigation and showed good results after the learning process. The results indicate that a learning environment with guided inquiry can be supported to improve the achievement in school (Ting Wen et al., 2020). The model of guided inquiry can be involved the students actively in the learning process from the scientific inquiry. It will be more likely to improve conceptual understanding than the strategies are more passive techniques, and need in the educational environment of current standard assessment requirements (Vlassi \& Karaliota, 2013).

Guided inquiry learning has the aim to develop and apply the skills such as problemsolving skills by self-study or teamwork and develop student's creativity. The students have an inspirational role to increase the potential and ability of students as the students. From the development of these skills, students are expected to be able to solve the problems faced by their environment well. Guided inquiry learning methods can improve the students' learning achievement and emphasizes the mastery of inquiry skills to overcome problems, so the students are trained to think, solve the problems and become independent learners (Yewang., 2017). The mastery of student's concepts who are taught with the learning of guided inquiry is more higher than students who are taught with conventional learning (Hariyadi et al., 2016).

The guided inquiry model gives a significant influence on students' learning achievement because it requires the students to be more active, be able to search and explore information outside the teacher's request and create new knowledge concepts so that the implementation of learning based guided inquiry model is more effective to 
improve students' scientific performance (Mulyana et al., 2018). With the increase of students' scientific performance, the science process skills by students will also increase so that it affects the learning achievement. This is following Ariani and her friends that the implementation of a guided inquiry learning model can improve science process skills and students' learning achievement because the students are allowed to build their knowledge. It is also in line with the research by Kholisatin and her friends that the development of learning tools based on guided inquiry with the REACT strategy is feasible and effective to improve the student's science process skills (Kholisatin et al., 2020). The increase of student's science process skills will increase to student's achievement (Ariani et al., 2015).

According to Wahyuningsih and her partner, a guided inquiry is the learning by providing solutions to the student in gaining their direct learning experience and developing their critical thinking in analyzing data obtained from the results of experimental activities. The learning activities are given a problem in everyday life and then the students are told to solve these problems through the process of inquiry learning with the stages of problem presentation, submit hypotheses, collect data to test the hypotheses, and make conclusions and reflections. By exposing students to real-life situations, student's knowledge will be more meaningful (Wahyuningsih et al., 2012). One of the right strategies to use is the REACT strategy.

The REACT strategy is the development of the contextual learning approach or Contextual Teaching and Learning (CTL). It is a learning approach that involved students in full to connected the material study with real-life contexts so that the knowledge is obtained by students is more meaningful (Johnson, 2011). With the contextual approach, teachers can be linked the topics to be taught with the context of real-life and encourage the students to connect their knowledge with its application in everyday life as a provision to solve the problems. In this case, it is expected that the learning process is more meaningful and take place naturally, the students can be actively involved and experienced not only the transfer of knowledge from teacher to student (Hamdayana, 2014). The REACT strategy is effective for refining alternative conceptions and helping students to maintain new conceptions in their long-term memory (Karsli \& Yigit, 2017). The REACT strategy has several stages namely relating, experiencing, applying, cooperating, and transferring. If the guided inquiry learning model is integrated with the REACT strategy, it will be more effective to improve the students' learning achievement. The REACT strategy is very effective to improve the students' learning achievement and gives a fairly high influence that is equal to $62 \%$ (Latifah et al., 2017).

The research of the pre-research that has been done by the researcher on several private course students shows that physics is a subject that is very difficult to understand. One of the physics material that is difficult to understand is heat and temperature. It is not an abstract material when it is associate with real life. The students said that learning in school is emphasizes with only formulas is used. After the students know some of the phenomena in real life are related to the heat and temperature material, the students assume that it is not abstract material again. Whereas, the students prefer the learning with experiments so that their knowledge received were more meaningful. This is following the research conducted by Amin, students are not accustomed to building knowledge or concepts from the results of the experiment. Teachers need to guide the process and experiment-based learning needs to be applied keeping in mind positive students' responses about the learning and 
increased understanding of concepts by students (Amin et al., 2012). Therefore, learning in school with a guided inquiry learning model with the REACT strategy is very suitable for use.

\section{Research Focus}

In the previous research, research by Koksal \& Berberoglu (2014), guided inquiry has been implemented to improve students' understanding of science concepts, students' achievement, and attitudes toward science. Research by Zaini (2016), guided inquiry gives a positive effect on the cognitive process learning achievement and students' critical thinking skills. Wongwatkit and his friends said that guided inquiry has been developed to improve students' learning performance and attitudes in Physics (Wongwatkit et al., 2017). Aulia and her friends, guided inquiry-based learning is effective to improve students' science literacy skills (Aulia et al., 2018). Next, Gunawan and his friends in his research said that the guided inquiry model has a positive effect to increase science process skills in physics learning, especially on skills: hypothesizing, practicing, and communicating (Gunawan et al., 2019). But in this research, the guided inquiry learning model has been specially designed to improve the students' learning achievement for the senior high school and integrated with the REACT strategy. The guided inquiry model consists of 6 phases, including 1) identifying the problem; (2) formulating a hypothesis; (3) data collecting; (4) data analyzing; (5) making a conclusions; (6) reflection and combine with the REACT strategy has several stages namely relating, experiencing, applying, cooperating and transferring. The purpose of this research is to effects of guided inquiry model with the REACT strategy learning materials to improve the students' learning achievement.

\section{RESEARCH METHOD}

This study uses a guided inquiry learning model with the REACT strategy learning materials to improve the students' learning achievement in the aspect of knowledge. Learning materials used consist of Syllabus, Lesson Plan (RPP), Student's Worksheet, Student's Textbook and Learning Achievement Tests developed with the 4D model and validated for two validators before being applied in the learning process. The learning kit was tested in class XI at one of the high school in Gresik by involving 35 students with using the One Group Pre-Test Post-Test Design model because the trial was conducted in one group without a comparison group (Sugiyono, 2017). The data collection methods used were validation, observation, and tests. For data analysis techniques in this study as follows:

\section{Analysis of Validation}

The validation of learning materials can be done by averaging the scores of each component given by the validator. The scoring scores of two validators are average on each component. Assessment of the validity of learning materials has a score of $1-4$ with a scale as follows.

Table 1. The criteria of validation.

\begin{tabular}{cc}
\hline Score & Category \\
\hline 1.00 & Very Invalid \\
2.00 & Invalid \\
3.00 & Valid \\
4.00 & Vey Valid \\
\hline
\end{tabular}




\section{Analysis of Students' Learning Achievement}

The scores can be obtained by calculation of scores from the number of students' correct answers in the work on the pre-test and post-test questions. The students' learning achievement can be analyzed with descriptive qualitative as follows:

- Completeness Analysis of Students' Learning Achievement

Students can be said complete if they are getting a value of $\geq 75$ (Minimum Completeness Criteria). Analysis of students' learning achievement can be seen from students' test results with individual completeness criteria as follows:

$$
\text { Individual completeness }=\frac{\text { Score obtained }}{\text { Total score }} \times 100
$$

To determine the completeness of students' learning achievement classically, it can be known by the following equation:

$$
\% \text { Completeness }=\frac{\text { Number of complete students }}{\text { Total number of students }} \times 100
$$

The learning can be stated classically complete if the learning achievement reaches $\geq 75 \%$.

\section{- Analysis of N-Gain}

The improve of students' learning achievement after participating in the learning process using learning materials of guided inquiry model with the REACT strategy can bee is known by a normalized gain test with the following equation:

$$
\langle g\rangle=\frac{\% \text { posttest score }-\% \text { pretest score }}{100 \%-\% \text { pretest score }}
$$

$\mathrm{N}$-gain can be identified based on the criteria for increasing the gain score as expressed by Hake as follows:

Table 3. The increase of N-gain criteria.

\begin{tabular}{c|c}
\hline Score gain & Criteria \\
\hline $0,00<g>0,30$ & Low \\
$0,30<g>0,70$ & Medium \\
$0,70<g>1,00$ & High \\
\hline
\end{tabular}

(Hake, 2002)

\section{Analysis of Students' Response}

Students' response data are obtained from the questionnaire responses of students after participating in the learning process using a guided inquiry model with the REACT strategy. The equation for calculating student's questionnaire response data are as follows:

$$
\text { Response }=\frac{\text { Number of aspect score that appeared }}{\text { Number of students }} \times 100 \%
$$

The collect data was processing and interpretation with the following criteria. 
Table 4. The criteria for interpretation of responden.

\begin{tabular}{c|c}
\hline Score & Category \\
\hline $0-20$ & Very Not Agree \\
$21-40$ & Not Agree \\
$41-60$ & Less Agree \\
$61-80$ & Agree \\
$81-100$ & Vey Agree \\
\hline
\end{tabular}

To find out the improvement of learning achievement, the Wilcoxon Signed Ranks Test is used because the samples are not normally distributed. The research data are processed descriptively. Learning materials can be said effective if the students' learning achievement has a value of $\geq 75$ (Minimum Completeness Criteria) with the percentage of completeness reach $\geq 75 \%$ and the students give positive responses in the range $61-100 \%$.

\section{RESULTS AND DISCUSSION}

\section{Learning Materials Validation}

The results of the average validity score of the guided inquiry with the REACT strategy learning materials can be seen in Table 5 .

Table 5. The average validity score of learning materials.

\begin{tabular}{lcc}
\hline \multicolumn{1}{c}{ Name } & Average Validity Score & Category \\
\hline Syllabus & 3.70 & Very Valid \\
Lesson Plan (RPP) & 3.56 & Valid \\
Student's Worksheet & 3.75 & Very Valid \\
Student's Textbook & 3.83 & Very Valid \\
Learning Achievement Tests & 3.81 & Very Valid \\
\hline
\end{tabular}

Based on the data obtained, it shows that learning materials based on the guided inquiry learning model with the REACT strategy have a very valid category and it can be used to the learning process.

\section{Students' Learning Achievement}

The results of the learning analysis on aspects of knowledge can be seen by pretest and posttest. The pretest is given before learning with a guided inquiry learning model with the REACT strategy while the post-test is given after learning takes place.

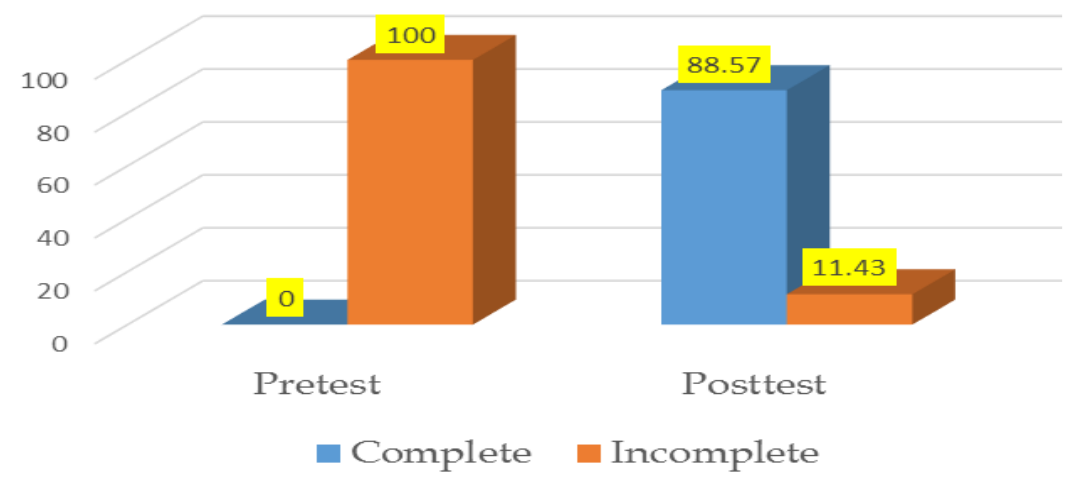

Figure 1. The completeness of students' learning achievement. 
Based on Figure 1, the pretest results of the knowledge aspect show that all of the students are incomplete. While the posttest, $88.57 \%$ of students are complete and $11.43 \%$ of students are incomplete. This is due to the students are not paying attention to the explanation from the teacher and not being serious at the test question. According to the Regulation of the Minister of Education and Culture of the Republic of Indonesia Number 23 Year 2016, the students can be said complete if they are getting a value of $\geq$ 75 (Minimum Completeness Criteria). The analysis of students' learning achievement can be seen in Table 6 .

Table 6. Students' learning achievement.

\begin{tabular}{c|c|c|c}
\hline Averages of Pretest Score & Averages of Posttest Score & Averages of N-Gain & Criteria \\
\hline 52 & 84 & 0.7 & Medium \\
\hline
\end{tabular}

After the learning activities are finished, the students are given a posttest using the same question instrument. Based on the results of the analysis, N-Gain which categorize as medium (can be seen in Table 6). Furthermore, the students are participating in learning activities using a guided inquiry learning model with the REACT strategy that teaches on heat and temperature materials to improve the students' learning achievement in the knowledge aspect. This is consistent with the research by Kusumandari which states that the inquiry learning with the REACT strategy has a significant effect on the physics learning achievement at senior high school students (Kusumandari, 2018). The research conducted by Almuntasheri and his friends that guided inquiry learning can be improved the student's understanding concepts. The guided inquiry learning can be supported the student in connecting new concepts with the concepts they have (Almuntasheri et al., 2016). To find out there is an increase in the students' learning achievement significantly or not, the Wilcoxon Signed Ranks Test is used, and the results can be seen in Table 7.

Table 7. Wilcoxon signed ranks test.

\begin{tabular}{c|c}
\hline & Post-Test - Pre-Test \\
\hline$Z$ & $-5.171^{\mathrm{b}}$ \\
Asymp. Sig. (2-tailed) & .000 \\
\hline
\end{tabular}

Based on the Wilcoxon Signed Rank Test, the $Z$ value is -5.171 with a P-value (Asymp. Sig. 2-tailed) of 0.000 which is less than the critical limit of research 0.05 so that the hypothesis decision is to accept $\mathrm{H}_{1}$ means there is a significant increase in students' learning achievement after participating the learning to use guided inquiry learning model with the REACT strategy. There is a significant influence when the learning process based on a guided inquiry learning model that can be seen from the improvement of students' cognitive abilities when implemented the learning (Rahayu et al., 2018). Furthermore, the research from Cahyono and his friends, that the REACT strategy is significantly on the skills of science process and student's physics learning achievement (Cahyono et al., 2017).

Based on the learning achievement, the learning materials based on the guided inquiry model with the REACT strategy is effective to improve the students' learning achievement. This is compatible with the research by Hitijahubessy which declare that the guided inquiry learning model is very effective to improve physics learning achievement of high school students on heat material, and the research by Hakim which state that the science physics learning with guided inquiry model is a very practical and 
effective way to improve the students' learning achievement that can be demonstrated by understanding student's concepts, student's psychomotor skills, and student's character which include discipline and responsibility. Margunayasa and his friends in their journal also concluded that the guided inquiry learning is more optimal to improve the students' learning achievement (Hitijahubessy, 2019; Hakim et al., 2015; Margunayasa et al., 2019). The REACT strategy is very effective to improve the students' learning achievement and gives a fairly high influence that is equal to $62 \%$ (Latifah et al., 2017).

\section{Students' Response}

The Students' response data related to learning with the implementation of a guided inquiry model with the REACT strategy to improve the students' learning achievement. It can be known by the results of the questionnaire filled out by students after the learning process using learning tools that were developed. The questionnaire sheets are included with eleven questions that must be filled honestly by students. The results of the analysis of the student's response can be seen in Table 8 .

Table 8. Analysis of the student's response.

\begin{tabular}{|c|c|c|c|c|c|}
\hline \multirow{2}{*}{ No. } & \multirow{2}{*}{ Question } & \multicolumn{4}{|c|}{ Answer } \\
\hline & & SS & $\mathbf{S}$ & TS & STS \\
\hline 1 & $\begin{array}{l}\text { The learning process with the guided inquiry model } \\
\text { by the REACT strategy, I have a high willingness to } \\
\text { participate in the learning of heat and temperature } \\
\text { material. }\end{array}$ & 18 & 17 & 0 & 0 \\
\hline \multicolumn{2}{|r|}{ Percentage $(\%)$} & \multicolumn{2}{|c|}{100.00} & \multicolumn{2}{|c|}{0.00} \\
\hline \multirow{2}{*}{\multicolumn{2}{|c|}{$\begin{array}{l}2 \text { The learning process is very interesting a } \\
\text { boring. } \\
\text { Percentage (\%) }\end{array}$}} & 23 & 12 & 0 & 0 \\
\hline & & \multicolumn{2}{|c|}{100.00} & \multicolumn{2}{|c|}{0.00} \\
\hline 3 & The learning process can foster my curiosity. & 22 & 13 & 0 & 0 \\
\hline \multicolumn{2}{|r|}{ Percentage $(\%)$} & \multicolumn{2}{|c|}{100.00} & \multicolumn{2}{|c|}{0.00} \\
\hline \multicolumn{2}{|r|}{$\begin{array}{l}4 \text { The learning process makes me more easily } \\
\text { understand and mastering the heat and temperature } \\
\text { material. }\end{array}$} & 22 & 13 & \multicolumn{2}{|c|}{0} \\
\hline \multicolumn{2}{|r|}{ Percentage $(\%)$} & \multicolumn{2}{|c|}{100.00} & \multicolumn{2}{|c|}{0.00} \\
\hline \multirow[t]{2}{*}{5} & $\begin{array}{l}\text { The learning materials, the learning condition, the } \\
\text { way of teacher teaches, and the direction stages in } \\
\text { the learning process are new and interest for me. }\end{array}$ & 14 & 20 & 1 & 0 \\
\hline & Percentage $(\%)$ & \multicolumn{2}{|c|}{97.14} & \multicolumn{2}{|c|}{2.86} \\
\hline 6 & $\begin{array}{l}\text { By the form of groups, I can more easily study and } \\
\text { discuss with my friends when I was finishing the } \\
\text { student's worksheet and understanding it more } \\
\text { easily to formulating problems, making hypotheses, } \\
\text { identifying variables, collecting data, analyzing data } \\
\text { and making conclusions. }\end{array}$ & 20 & 15 & 0 & 0 \\
\hline \multicolumn{2}{|r|}{ Percentage $(\%)$} & \multicolumn{2}{|c|}{100.00} & \multicolumn{2}{|c|}{0.00} \\
\hline \multirow[t]{2}{*}{7} & $\begin{array}{l}\text { The teacher was giving an easy explanation when } \\
\text { the learning process }\end{array}$ & 19 & 15 & 1 & 0 \\
\hline & Percentage $(\%)$ & \multicolumn{2}{|c|}{97.14} & \multicolumn{2}{|c|}{2.86} \\
\hline 8 & $\begin{array}{l}\text { Learning material is associate with everyday life so } \\
\text { that it makes be happier. }\end{array}$ & 16 & 19 & 0 & 0 \\
\hline \multicolumn{2}{|r|}{ Percentage ( $\%)$} & \multicolumn{2}{|c|}{100.00} & \multicolumn{2}{|c|}{0.00} \\
\hline 9 & The student's worksheet is easier to understand. & 15 & 20 & 0 & 0 \\
\hline
\end{tabular}




\begin{tabular}{|c|c|c|c|c|c|}
\hline \multirow{2}{*}{ No. } & \multirow{2}{*}{ Question } & \multicolumn{4}{|c|}{ Answer } \\
\hline & & SS & $\mathbf{S}$ & TS & STS \\
\hline \multicolumn{2}{|r|}{ Percentage (\%) } & \multicolumn{2}{|c|}{100.00} & \multicolumn{2}{|c|}{0.00} \\
\hline 10 & $\begin{array}{l}\text { The tests are given by the teacher during the } \\
\text { learning process. }\end{array}$ & 17 & 18 & 0 & 0 \\
\hline \multicolumn{2}{|r|}{ Percentage (\%) } & \multicolumn{2}{|c|}{100.00} & \multicolumn{2}{|c|}{0.00} \\
\hline \multirow[t]{5}{*}{11} & $\begin{array}{l}\text { I get more motivation to study physics on heat and } \\
\text { temperature topics after the learning process with } \\
\text { the guided inquiry model by the REACT strategy. }\end{array}$ & 12 & 22 & 1 & 0 \\
\hline & Percentage (\%) & \multicolumn{2}{|c|}{97.14} & \multicolumn{2}{|c|}{2.86} \\
\hline & Total & 198 & 184 & 3 & 0 \\
\hline & Overal Percentage (\%) & 51.43 & 47.79 & 0.78 & 0.00 \\
\hline & Total Percentage (\%) & \multicolumn{2}{|c|}{99.22} & \multicolumn{2}{|c|}{0.78} \\
\hline
\end{tabular}

SS: Very Agree; S: Agree; TS: Disagree; STS: Very Disagree

The student's responses to learning activity using the development of learning materials can be seen from the questionnaire. In the response questionnaire, there are eleven questions given to students. From the results, it can be concluded that the students are provided a good response to learning using a guided inquiry learning model by REACT strategy with a percentage score of $99.22 \%$ in the range of answers are very agree and agree. This is in accordance with the research by Hilman, that the students are given a positive response to guided inquiry learning of $92.94 \%$ (Hilman, 2014). The results of the analysis of the student's response can be seen in Table 4, while the percentage diagram of the response can be seen in Figure 2.

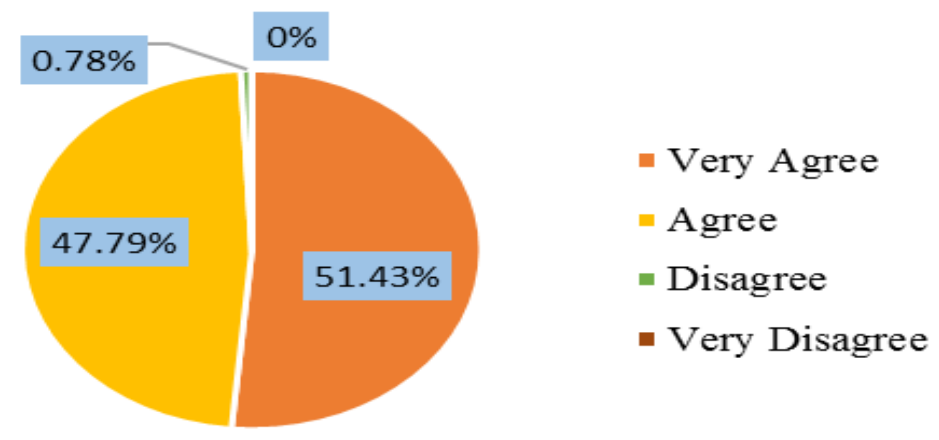

Figure 2. The percentage of student's response.

Figure 2 shows that the learning process can be encouraged students to have a high willingness to followed the learning process because it is felt to be very interested and not bored. This can be known about a percentage of answers in the questionnaire responses of students at the first to the fourth statements with a percentage of answers of $100.00 \%$. It is relevant what Bandura said that students must have been interested in something in learning so that students can be learned to the maximum (Moreno, 2010).

Based on the description of the results of the study above it can be concluded that the guided inquiry learning model with the REACT strategy can motivate the student to learn. Because the learning process involved students fully to actively build their knowledge from inquiry activities. The problems given to students include problems in everyday life, so the knowledge has received by students will be more meaningful. The investigation activities can help the students to solve problems and improve students' 
science process skills. The increase of science process skills, students will be more skilled in learning so that students' learning achievement will increase.

\section{CONCLUSIONS}

Based on the results obtained, the conclusion is that the guided inquiry learning model with the REACT strategy learning materials is very effective to improve the students' learning achievement. It can be seen from $88.57 \%$ of the learning achievement from students achieving completeness and students gave $99.22 \%$ responses in the range of agree and very agreeable. Guided inquiry with the REACT strategy learning is expected to be able to make students more actively in the process of gaining their knowledge directly so that students are easier to remember and interpret. From this interpretation, students can more easily understand the concept and influence the learning achievement they obtain. The effectiveness of learning materials is only reviewed from the results of students' learning achievement on aspects of knowledge and student's response, so for the readers who want to conduct relevant research to this research, the effectiveness of learning materials can be reviewed from other aspects.

\section{ACKNOWLEDGEMENTS}

Thank you to the Universitas Negeri Surabaya for supporting and funding in this research.

\section{REFERENCES}

Almuntasheri, S., Gillies, R.M., \& Wright, T. (2016). The effectiveness of a guided inquiry-based, teachers' professional development programme on saudi students' understanding of density. Science Education International, 27(1), 16-39

Amin, R. A., Jatmiko, B., \& Prastowo, T. (2012). Pengembangan perangkat pembelajaran fisika sma model guided inquiry untuk meningkatkan pemahaman konsep siswa materi listrik dinamis. Jurnal Penelitian Pendidikan Sains, 1(2), 56-61.

Ariani, M., Hamid, A., \& Leny. (2015). Meningkatkan keterampilan proses sains dan hasil belajar siswa pada materi koloid dengan model inkuiri terbimbing pada siswa kelas XI IPA 1 SMA Negeri 11 Banjarmasin. Jurnal Inovasi Pendidikan Sains, 6(1), 98-107.

Aulia, E.V., Poedjiastoeti, S., \& Agustini, R. (2018, January). The effectiveness of guided inquiry-based learning material on students' science literacy skills. Journal of Physics: Conference Series, 947(1).

Baharuddin. (2014). Teori belajar dan pembelajaran. Yogyakarta: Arruz Media.

Cahyono, B.A., Sutarto, \& Mahardika, I.K. (2017). Model pembelajaran REACT (Relating, Experiencing, Applying, Cooperating and Transfering) disertai Media video kejadian fisika terhadap keterampilan proses sains dan hasil belajar siswa dalam pembelajaran di SMA. Jurnal Edukasi, 4(3), 20-24.

Friesen, J.W. (2012). The deep historical roots of inquiry learning. Jurnal Pendidikan Malaysia, 37(1), 47-55.

Gunawan, G., Harjono, A., Hermansyah, H., \& Herayanti, L. (2019). Guided inquiry model through virtual laboratory to enhance students' science process skills on heat concept. Jurnal Cakrawala Pendidikan, 38(2), 259-268.

Hake, R.R. (2002). Relationship of individual student normalized learning gains in mechanics with gender, high-school physics, and pretest scores on mathematics and spatial visualization. Boise, Idaho: Physics Education Research Conference. 
Hakim, M.L., Prabowo, \& Yuanita, L. (2015). Pengembangan perangkat pembelajaran fisika model inkuiri terbimbing sebagai upaya meningkatkan hasil belajar siswa pada materi kalor di SMA. Jurnal Penelitian Pendidikan Sains, 5(1), 764-768.

Hamdayana, J. (2014). Model dan metode pembelajaran kreatif dan berkarakter. Bogor: Ghalia Indonesia.

Hariyadi, D., Ibrohim, \& Rahayu, S. (2016). Pengaruh model pembelajaran inkuiri terbimbing berbasis lingkungan terhadap keterampilan proses dan penguasaan konsep IPA siswa kelas VII pada materi ekosistem. Jurnal Pendidikan: Teori, Penelitian dan Pengembangan, 1(8), 1567-1574.

Hilman. (2014). Pengaruh pembelajaran inkuiri terbimbing dengan mind map terhadap keterampilan proses sains dan hasil belajar IPA. Jurnal Pendidikan Sains, 2(4), 221229.

Hitijahubessy, M.F. (2019). Pengembangan perangkat pembalajaran fisika pada materi kalor berorientasi model inkuiri terbimbing (guided inqury) untuk meningkatkan hasil belajar siswa SMA. Surabaya: Pascasarjana Universitas Negeri Surabaya.

Johnson, E.B. (2011). Contextual teaching and learning: Menjadikan kegiatan belajar mengajar mengasyikkan dan bermakna. Bandung: Mizan Media Utama.

Karsli, F., \& Yigit, M. (2017). Effectiveness of the REACT strategy on 12th grade students' understanding of the alkenes concept. Research in Science $\mathcal{E}$ Technological Education, 35(3), 274-291.

Kesuma, D., Surya, E., \& Syahputra, E. (2019). The evaluation of authentic assessment implementation in the kurikulum 2013 at SD Negeri 067690 Medan. Budapest International Research and Critics in Linguistics and Education (BirLE) Journal, 2(4), 415-425.

Kholisatin, S., Imam Supardi, Z.A., \& Suprapto, N. (2020). Development of lesson devices used guided inquiry learning with color material REACT strategy to improve science skills process on elementary school students. International Journal of Innovative Science and Research Technology, 5(2), 209-2015.

Koksal, E.A., \& Berberoglu, G. (2014). The effect of guided-inquiry instruction on 6th grade Turkish students' achievement, science process skills, and attitudes toward science. International Journal of Science Education, 36(1), 66-78.

Kusumandari, D. E. (2018). Implementasi model pembelajaran inkuiri menggunakan strategi REACT untuk meningkatkan hasil belajar fisika siswa SMA. Bandar Lampung: Universitas Lampung.

Latifah, S., Komikesari, H., \& Ulum, M. (2017). Efektivitas strategi REACT (Relating, Experiencing, Applying, Cooperating, Transfering) terhadap hasil belajar dan keterampilan proses sains di SMPN 22 Bandar Lampung. Jurnal Penelitian Pembelajaran Fisika, 8(2), 101-108.

Margunayasa, I.G., Dantes, N., Marhaeni, \& Suastra, I.W. (2019). The effect of guided inquiry learning and cognitive style on science learning achievement. International Journal of Instruction, 12(1), 737-750.

Mohamad, N. (2011). Model pembelajaran kooperatif. Surabaya: Unesa.

Moreno, R. (2010). Educational psychology. New Mexico. John Wiley \& Sons, Inc.

Muhafid, E. A. (2015). Peningkatan scientific skills siswa melalui implementasi model Problem Based Learning (PBL) pada pembelajaran IPA Di SMP/MTS kelas VII. In Seminar Nasional Pendidikan Sains V 2015. Sebelas Maret University. 
Mulyana, S., Rusdi, \& Vivanti, D. (2018). The effect of guided inquiry learning model and scientific performance on student learning outcomes. Indonesian Journal of Science and Education, 2(1), 105-109.

Muslimin, R., Widodo, A. T., \& Priatmoko, S. (2019). Pengaruh pembelajaran inkuiri terbimbing berstrategi REACT terhadap hasil belajar kimia. Journal of Chemistry in Education, 1-6.

Nizar, M. (2018). Pengembangan perangkat pembelajaran model inkuiri terbimbing untuk meningkatkan keterampilan berpikir kreatif siswa SMA Negeri 1 Balongoanggang. Surabaya: Unesa.

Rahayu, A. B., Hadi, S., Istyadji, M., Zaini, M., Sholahuddin, A., \& Fahmi. (2018). Development of guided inquiry based learning devices to improve student learning outcomes in science materials in middle school. European Journal of Alternative Education Studies, 3(2), 107-117.

Riduwan. (2012). Belajar mudah penelitian. Bandung: Alfabeta.

Sugiyono. (2017). Metode penelitian kuantitatif kualitatif dan $R \mathcal{E}$ D. Bandung: Alfabeta.

Suparno, P. (2013). Metodologi pembelajaran fisika konstruktivistik dan menyenangkan. Yogyakarta: Universitas Sanata Dharma.

Ting Wen, C., Chung Liu, C., Yi Chang, H., Jung Chang, C., Hua Chang, M., Chiang, S. H., Hwang, F. K. (2020). Students' guided inquiry with simulation and its relation to school science achievement and scientific literacy. ScienceDirect Procedia - Social and Behavioral Science, 149, 103830.

Vlassi, M., \& Karaliota, A. (2013). The comparison between guided inquiry and traditional teaching method. a case study for the teaching of the structure of matter to 8th grade greek students. Science Direct Procedia - Social and Behavioral Sciences, 93, 494-497.

Wahyuningsih, I., Sarwi, \& Sugianto. (2012). Penerapan model kooperatif group investigation berbasis eksperimen inkuiri terbimbing untuk meningkatkan aktivitas belajar. Journal of Physics Theacher Education, 2(3), 1-26.

Wongwatkit, C., Panjaburee, P., \& Srisawasdi, N. (2017). A proposal to develop a guided-inquiry mobile learning with a mastery learning mechanism for improving students' learning performance and attitudes in Physics. International Journal of Mobile Learning and Organisation, 11(1), 63-86.

Yewang, M.U. (2017). The Effect Of Guided Inquiry Vs Free Inquiry Instruction Method And Learning Motivation On Student Learning Outcomes. IOSR Journal of Research $\mathcal{E}$ Method in Education (IOSR-JRME), 7(5), 36-43

Zaini, M. (2016). Guided inquiry based learning on the concept of ecosystem toward learning outcomes and critical thinking skills of high school students. IOSR Journal of Research \& Method in Education (IOSR-JRME), 6(6), 50-55. 


\footnotetext{
*Miftahul Jannah (Corresponding Author)

Universitas Negeri Surabaya, Postgraduate School, Science Education Study Program, Continuing Program Development, Jl. Unesa Lidah Wetan, Surabaya, East Java, 60213, Indonesia

Email: $\underline{\text { miftahul.18055@mhs.unesa.ac.id }}$

Dr. Z. A. Imam Supardi, M.Si.

Universitas Negeri Surabaya, Postgraduate School, Science Education Study Program, Continuing Program Development, Jl. Unesa Lidah Wetan, Surabaya, East Java, 60213, Indonesia

Email: zsupardi@gmail.com

Prof. Dr. Prabowo, M.Pd.

Universitas Negeri Surabaya, Postgraduate School, Science Education Study Program, Continuing Program Development, Jl. Unesa Lidah Wetan, Surabaya, East Java, 60213, Indonesia

Email: prabowo@unesa.ac.id
} 